\title{
Ragam Genetik dan Heritabilitas Peubah Kualitatif dan Peubah Kuantitatif Dua Puluh Genotipe Cabai (Capsicum annuum L.)
}

\author{
Genetic Variation and Heritability of Qualitative and Quantitative \\ Variables of Twenty Chili Genotypes (Capsicum annuum L.) \\ Lasmiana $^{1^{*}}$, Dwi Wahyuni Ganefianti ${ }^{1}$, Alnopri ${ }^{1}$ \\ ${ }^{1} J u r u s a n$ Budidaya Pertanian, Fakultas Pertanian UNIB \\ *:Lasmiana94@gmailcom
}

\begin{abstract}
Chili development in Indonesia faces several constraints, mainly low yields and disease incidents. The improvement of chili traits through breeding programs requires information of genetic diversity, heritability, genetic advance and gene role. A study was conducted to assess the values of variability and heritability of qualitative and quantitative traits of 20 genotypes of chilli plants. The study was conducted in May-September 2015 on Experimental Field of Faculty of Agriculture, the University of Bengkulu. The 20 chili genotypes were arranged factorially in a Randomized Complete Block Design, with three replications. The results showed that the qualitative characters that have broad sense of variability and heritability were plant height, days to flower, time to harvest, fruit length, fruit diameter, fruit weight, and weight of fruit per plant, indicating that a selection can be done on those variables. Variability on qualitative characters was found on the position of the flower stalk (3 kinds), corolla color (4 kinds), color of corolla holder (3 kinds), corolla shapes (2 kinds), anther colors (4 kinds), pistil colors (3 kinds), colors of young fruit and ripe fruit (3 kinds), and fruit position (3 kinds).
\end{abstract}

Key words: chilli, heritability, qualitative traits , quantitative traits, variability

\begin{abstract}
ABSTRAK
Kendala pengembangan cabai di Indonesia adalah rendahnya daya hasil dan adanya serangan penyakit. Salah satu upaya untuk meningkatkan produksi dan kualitas cabai adalah melalui program pemuliaan tanaman. Perbaikan karakter cabai melalui program pemuliaan tanaman membutuhkan informasi keragaman genetik,nilai heritabilitas, kemajuan genetik dan peran gen. Tujuan penelitian ini adalah untuk menaksir nilai variabilitas dan heritabilitas peubah kualitatif dan peubah kuantitatif 20 genotipe tanaman cabai. Penelitian dilaksanakan pada bulan Mei - September 2015 di Kebun Percobaan Fakultas Pertanian, Universitas Bengkulu. Penelitian disusun dalam Rancangan Kelompok Lengkap Teracak, faktor tunggal terdiri atas 20 genotipe cabai dengan tiga ulangan. Hasil penelitian menunjukkan bahwa karakter kualitatif yang memiliki tingkat keragaman yang luas dan heritabilitas yang tinggi adalah tinggi tanaman, umur berbunga, umur panen, panjang buah, diameter buah, bobot buah, dan bobot buah per tanaman. Seleksi dapat dilakukan pada buah tersebut. Keragaman pada karakter kualitatif adalah posisi tangkai bunga 3 macam, warna corolla 4 macam, warna tempat corolla 3 macam, bentuk corolla 2 macam, warna anther 4 macam, warna tangkai putik 3 macam, warna buah muda dan buah masak 3 macam, posisi buah 3 macam.
\end{abstract}




\section{PENDAHULUAN}

Cabai (Capsicum annuum L.) merupakan komoditas sayuran penting di Indonesia, dikonsumsi dalam bentuk segar maupun olahan. Cabai dikonsumsi untuk memenuhi kebutuhan rumah tangga yaitu sebagai bahan pelengkap makanan atau rempah dan ramuan obat-obatan tradisional. Seiring dengan kebutuhan manusia dan teknologi yang semakin berkembang, cabai juga digunakan sebagai bahan baku industri untuk obat-obatan, zat warna, dan lainnya (Maflahah, 2010). Produksi cabai segar dengan tangkai tahun 2015 sebesar 1.075 juta ton. Dibandingkan tahun 2014, terjadi kenaikan produksi sebesar 61.73 ribu ton (6.09 persen). Kenaikan ini disebabkan oleh kenaikan produktivitas sebesar 0.19 ton per hektar (2.33 persen) dan peningkatan luas panen sebesar 4.62 ribu hektar (3.73 persen) dibandingkan tahun 2014 (BPS, 2015).

Pengembangan tanaman cabai di Indonesia mengalami kendala yaitu rendahnya daya hasil dan adanya serangan penyakit (Semangun, 2008). Salah satu upaya untuk meningkatkan produksi dan kualitas hasil cabai adalah melalui program pemuliaan tanaman. Pemuliaan tanaman merupakan rangkaian kegiatan penelitian dan pengujian atau kegiatan penemuan dan pengembangan suatu varietas, sesuai dengan metode baku untuk menghasilkan varietas baru dan mempertahankan kemurnian benih varietas yang dihasilkan. Koleksi berbagai genotipe yang berasal dari berbagai daerah di Indonesia maupun di luar negeri merupakan sumber keragaman yang penting dalam melakukan pemuliaan tanaman. Perbaikan karakter tanaman cabai melalui program pemuliaan tanaman membutuhkan informasi keragaman genetik, nilai heritabilitas, kemajuan genetik dan peran gen yang mempengaruhi fenotipe populasi tanaman tersebut sebagai kajian genetik awal (Syukur et al., 2010).

Keragaman genetik cabai yang luas merupakan modal dasar bagi program pemuliaan tanaman. Sujiprihati et al. (2008) menyatakan bahwa keanekaragaman populasi tanaman memiliki arti penting dalam pemuliaan tanaman. Keragaman genetik dapat diperoleh melalui berbagai cara antara lain introduksi, mutasi, hibridisasi, ploidisasi dan rekayasa genetika (bioteknologi). Beberapa penelitian tentang keragaman genetik, heritabilitas dan pewarisan pada cabai telah dilakukan oleh beberapa peneliti seperti Sreelathakumary dan Rajamony (2004), Lestari et al. (2006), Hilmayanti et al. (2006), Smitha and Basvaraja (2007), Marame et al. (2008), Ajjapplavara dan Channagoudra (2009), Sharma et al. (2010) dan Ganefianti et al. (2014).

Heritabilitas adalah parameter genetik yang digunakan untuk mengukur kemampuan suatu genotipe dalam populasi tanaman untuk mewariskan karakter yang dimilikinya atau suatu pendugaan yang mengukur sejauh mana variabilitas penampilan suatu genotipe dalam populasi terutama yang disebabkan oleh peranan faktor genetik. Heritabilitas suatu karakter penting diketahui, terutama untuk menduga besarnya pengaruh lingkungan terhadap pertumbuhan dan perkembangan tanaman serta pemilihan lingkungan yang sesuai untuk proses seleksi (Susanto dan Adie, 2005). Menurut Sujiprihati et al. (2008) populasi yang memiliki nilai heritabilitas yang tinggi akan lebih mudah dilakukan perbaikan karakter melalui seleksi dibandingkan dengan populasi yang bernilai heritabilitas rendah. Nilai kemajuan genetik mencerminkan besarnya kemajuan perbaikan karakter yang dapat dicapai bila dilakukan seleksi. Berdasarkan hal tersebut maka penelitian mengenai peningkatan mutu cabai melalui program pemuliaan tanaman untuk menghasilkan varietas baru sangat diperlukan. 
Tujuan penelitian ini adalah untuk menaksir nilai variabilitas dan heritabilitas peubah kualitatif dan peubah kuantitatif 20 genotipe tanaman cabai.

\section{METODE PENELITIAN}

Penelitian dilaksanakan pada bulan Mei sampai September 2015 di kebun percobaan Fakultas Pertanian, Universitas Bengkulu. Bahan yang digunakan adalah 20 genotipe cabai yaitu IPB C19, C1108, Kopay, UNIBC GTS1, IPC14, Hot Papper Tornado, IPBC4, Koleksi IPB B, Koleksi IPB P, SELOKA, ANIES, SSP, Dark Green Papper, Pueddes, Bird Type, Laris, Trisula, Ferosa, IPB-57, dan Wulung. Percobaan disusun dalam Rancangan Kelompok Lengkap Teracak (RKLT), faktor tunggal dengan tiga ulangan. Tanaman ditanam dalam barisan. Setiap baris ditanam 1 genotipe berjumlah 10 tanaman, dengan 5 tanaman sebagai sampel. Peubah yang diamati adalah peubah kualitatif dan kuantitatif. Peubah kualitatif yaitu posisi tangkai bunga, warna dasar bunga, warna tempat corolla, bentuk corrola, warna anther, warna tangkai putik, warna buah muda, warna buah masak dan posisi buah. Peubah kuantitatif yaitu tinggi tanaman, waktu berbunga, umur panen, panjang buah, diameter buah, bobot perbuah, dan bobot buah pertanaman.

Pelaksanaan penelitian secara umum terbagi dalam empat tahap, yakni persemaian, penanaman, pemeliharaan dan pemanenan. Media semai terdiri dari campuran tanah, pupuk kandang dan sekam dengan perbandingan 2:1:1. Bibit yang telah mempunyai 6 helai daun siap dipindahkan ke lahan. Bedengan dibuat dengan ukuran $6 \mathrm{~m} \times 1 \mathrm{~m}$ dengan jarak tanam 60 $\mathrm{cm} \times 50 \mathrm{~cm}$ dan ukuran lubang tanam 20 $\mathrm{cm} \times 20 \mathrm{~cm} \times 20 \mathrm{~cm}$.

Pemeliharaan tanaman di lapangan meliputi penyulaman, pengajiran, pewiwilan, pemupukan, dan pengendalian organisme pengganggu tanaman. Satu minggu setelah penanaman dilakukan penyulaman terhadap bibit cabai yang mati. Pewiwilan dilakukan dengan membuang tunas-tunas air di ketiak daun di bawah cabang dikotomus. Pengendalian gulma dilakukan secara manual, sedangkan pengendalian terhadap hama dan penyakit dilakukan secara manual dan kimiawi. Panen dilakukan terhadap buah cabai yang telah berwarna merah lebih dari 50\%. Panen dilakukan sejak setengah dari populasi tersebut telah berbuah merah $50 \%$. Panen diutamakan terhadap tanaman contoh, dan pada akhir panen buah yang tersisa dan sudah memenuhi kriteria panen di panen seluruhnya.

Ada dua macam analisis untuk data peubah yang diamati yaitu analisis deskriptif untuk data peubah kualitatif dan analisis ragam untuk data peubah kuantitatif.

\section{HASIL DAN PEMBAHASAN}

\section{Peubah Kuantitatif}

Hasil analisis ragam peubah kuantitatif 20 genotipe cabai yang diamati menunjukkan berbeda sangat nyata hampir pada semua karakter kecuali diameter batang (Tabel 1). Hasil penelitian Ganefianti et al. (2006) terdapat perbedaan nyata antar galur pada variabel tinggi tanaman panen pertama, tinggi tanaman panen terakhir, umur berbunga, umur panen, panjang buah, diameter buah, jumlah dan bobot satu buah. Hasil penelitian Qosim et al. (2013) juga menyatakan bahwa hasil uji -F pada tanaman cabai beberapa karakter memiliki perbedaan yang nyata, seperti karakter panjang tangkai buah, panjang tangkai daun, diameter buah, jumlah buah per tanaman, jumlah buah per plot, bobot per buah, bobot buah per tanaman, dan bobot buah per plot. 
Untuk mengetahui keragaman suatu tanaman dapat dilihat melalui nilai varians genetik seperti Standar deviasi ragam $\left(\sigma_{\sigma}^{2} g\right), 2$ kali standar deviasi ragam $(2 \mathrm{x}$ $\sigma_{\sigma}{ }^{2} g$ ), Ragam genetik $\left(\sigma^{2} g\right)$ dan Heritabilitas (Tabel 2).

\section{Tinggi Tanaman (cm)}

Dari 20 genotipe cabai yang diteliti, peubah tinggi tanaman menunjukkan ragam genetik yang luas, dimana nilai ratarata tinggi tanaman cabai yang diamati antara $36.73-56.27 \mathrm{~cm}$. Rata-rata tertinggi yaitu pada genotipe Kopay sedangkan yang terendah pada genotipe Koleksi IPB P. Semua genotipe yang diamati pada peubah tinggi tanaman memiliki dugaan nilai heritabilitas yang tinggi sehingga pada keseluruhan genotipe yang digunakan dapat dilakukan seleksi. Dengan nilai dugaan heritabilitas yang tinggi maka seleksi untuk sifat tinggi tanaman dapat dilakukan pada generasi awal.

Semakin tinggi suatu tanaman maka akan semakin jauh pula jarak buah dari permukaan tanah sehingga akan memperkecil kemungkinan penularan cendawan dari permukaan tanah ke buah tanaman. Kirana dan Sofari (2007) menyatakan bahwa semakin tinggi tanaman menunjukkan bahwa tanaman tersebut juga tinggi sehingga jarak buah dari tanah akan semakin jauh dan dapat memperkecil infeksi cendawan yang terbawa oleh percikan air ketika menyiram maupun hujan.

\section{Waktu Berbunga (HST) dan Umur Panen (HST)}

Dari 20 genotipe cabai yang diteliti, peubah waktu berbunga menunjukkan ragam genetik yang luas, dimana nilai ratarata waktu berbunga cabai yang diamati antara 40-50.33 HST. Rata-rata tertinggi yaitu pada genotipe UNIB C GTS1 se-

Tabel 1. Hasil analisis ragam peubah kuantitatif 20 genotipe cabai

\begin{tabular}{lc}
\hline Peubah yang diamati & KT-Genotipe \\
\hline Tinggi tanaman & $4.15^{* *}$ \\
Waktu berbunga & $24.84^{* *}$ \\
Umur Panen & $6.85^{* *}$ \\
Panjang buah & $66.28^{* *}$ \\
Diameter buah & $23.75^{* *}$ \\
Bobot perbuah & $19.82^{* *}$ \\
Bobot buah pertanaman & $13.14^{* *}$ \\
\hline
\end{tabular}

Keterangan : ${ }^{*}=$ berbeda sangat nyata taraf $1 \%$ uji $\mathrm{F}, \mathrm{ns}=$ tidak berbeda nyata taraf $5 \%$ uji $\mathrm{F}$

Tabel 2. Standar deviasi ragam, ragam genetik dan heritabilitas beserta klasifikasinya pada semua peubah kuantitatif 20 genotipe cabai

\begin{tabular}{lrrrr}
\hline \multicolumn{1}{c}{ Peubah yang diamati } & $\begin{array}{c}\text { Standar } \\
\text { deviasi ragam } \\
\left(\sigma_{\sigma^{2}} g\right)\end{array}$ & $\begin{array}{c}\text { 2 kali standar } \\
\text { deviasi ragam } \\
\left(2 \mathrm{x} \sigma_{\sigma^{2}} g\right)\end{array}$ & $\begin{array}{c}\text { Ragam genetik ( } \\
\left.\sigma^{2} g\right)\end{array}$ & $\begin{array}{c}\text { Heritabilitas } \\
\text { (kriteria) }\end{array}$ \\
\hline Tinggi tanaman & 12.86 & 25.72 & $31.32($ Luas) & Tinggi \\
Waktu berbunga & 4.13 & 8.26 & 12.89 (Luas) & Tinggi \\
Umur Panen & 1.06 & 2.12 & 2.92 (Luas) & Tinggi \\
Panjang buah & 6.78 & 7.98 & 12.81 (Luas) & Tinggi \\
Diameter buah & 1.33 & 2.66 & 4.16 (Luas) & Tinggi \\
Bobot perbuah & 0.48 & 0.96 & 1.49 (Luas) & Tinggi \\
Bobot buah pertanaman & 354.65 & 709.3 & 1065.44 (Luas) & Tinggi \\
\hline
\end{tabular}


dangkan yang terendah pada genotipe 9 (Hot Papper Tornado). Nilai duga heritabilitas pada peubah waktu berbunga menunjukkan kriteria yang luas sehingga seleksi pada peubah ini dapat dilakukan. Hal ini sesuai dengan hasil penelitian Qosim et al. (2013) yang menyatakan bahwa nilai duga heritabilitas pada peubah waktu berbunga adalah tinggi.

Waktu berbunga suatu tanaman akan mempengaruhi umur panen tanaman tersebut. Syukur et al. (2012) menyatakan waktu berbunga menjadi salah satu faktor untuk menentukan apakah varietas tersebut unggul atau tidak. Varietas yang unggul adalah varietas yang memiliki umur panen singkat (genjah). Dermawan (2006) menyatakan bahwa perbedaan umur berbunga dan umur panen dapat disebabkan oleh beberapa faktor yaitu unsur hara, lama penyinaran matahari, suhu, kelembaban dan tanah.

Dari 20 genotipe cabai yang diteliti, peubah umur panen menunjukkan ragam genetik yang luas. Rata-rata umur panen antara 75.67-82.33 HST. Rata-rata tertinggi pada genotipe UNIBC GTS1 sedangkan terendah yaitu genotipe Koleksi IPB P. Nilai duga heritabilitas pada peubah waktu berbunga menunjukkan kriteria yang luas menunjukkan bahwa umur panen dipengaruhi oleh faktor genetik sehingga seleksi pada peubah ini dapat dilakukan. Hal ini sesuai dengan hasil penelitian Salamah (2013) yang menyatakan bahwa nilai duga heritabilitas pada 25 genotipe cabai yang diamati untuk peubah umur panen adalah tinggi. Secara umum tanaman yang berbunga lebih cepat maka umur panennya juga akan cepat. Umur panen adalah salah satu kriteria cabai unggul (Syukur et al. 2012).

\section{Panjang Buah (cm) dan Diameter Buah (mm)}

Untuk peubah panjang buah dan diameter buah dari 20 genotipe cabai yang diteliti, menunjukkan ragam genetik yang luas, dimana nilai rata-rata panjang buah cabai yang diamati antara $2.79-16.91 \mathrm{~cm}$. Rata-rata tertinggi yaitu pada genotipe Bird type sedangkan yang terendah pada genotipe Hot Papper Tornado. Nilai rata-rata diameter buah cabai yang diamati antara 5.17$11.74 \mathrm{~mm}$. Rata-rata tertinggi yaitu pada genotipe $\mathrm{C} 1108$ sedangkan yang terendah pada genotipe Koleksi IPB B. Nilai duga heritabilitas pada peubah panjang buah dan diameter buah menunjukkan kriteria yang luas sehingga seleksi pada peubah ini dapat dilakukan. Hal ini sesuai dengan hasil penelitian Ramadhani et al. (2013) menyatakan bahwa nilai duga heritabilitas dan keragaman genetik yang diamati memiliki kriteria yang tinggi dan luas pada peubah diameter buah dan panjang buah. Di dukung hasil penelitian Syukur et al. (2011) dan Lestari et al. (2006) peubah diameter buah dan panjang buah memiliki nilai duga heritabilitas yang tinggi.

Saputra et al. (2013) mengemukakan bahwa berdasarkan pandangan pemuliaan tanaman, untuk mendapatkan varietas cabai yang unggul, pemilihan genotipe yang memiliki panjang buah, tebal daging buah, diameter buah dan bobot perbuah merupakan upaya yang dapat dilakukan untuk meningkatkan produksi cabai. Buah yang besar dan bagus lebih di sukai oleh konsumen.

\section{Bobot Perbuah (g) dan Bobot buah per- tanaman (g)}

Untuk peubah bobot perbuah dan bobot buah pertanaman dari 20 genotipe cabai yang diteliti, menunjukkan ragam genetik luas untuk peubah dimana nilai rata-rata bobot perbuah cabai yang di amati antara 0.80-4.96 gr. Rata-rata tertinggi yaitu pada genotipe C1108 sedangkan yang terendah pada genotipe Koleksi IPB P. Nilai rata-rata bobot buah pertanaman cabai yang diamati antara 50.85-154.15 


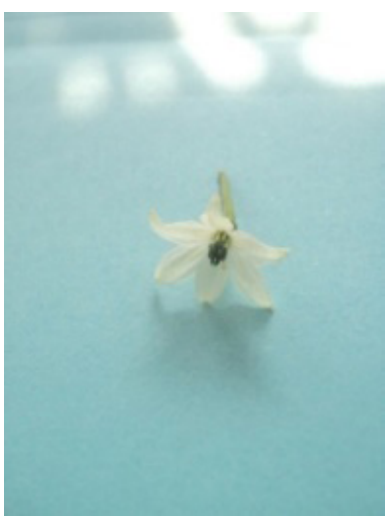

(a)

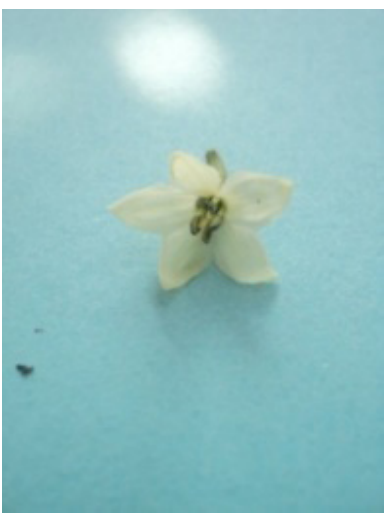

(b)

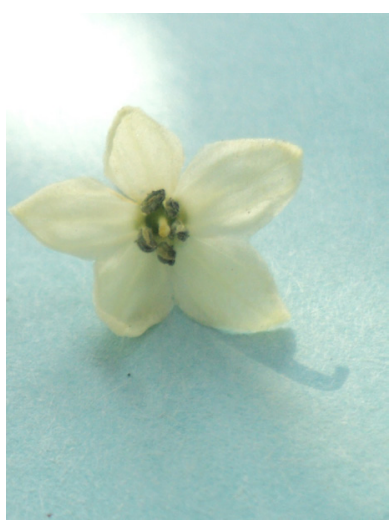

(c)

Gambar 1. Warna corola cabai yang diuji : (a) putih (8 genotipe) (b) putih kekuningan (7 genotipe) (c) putih kehijauan (4 genotipe)

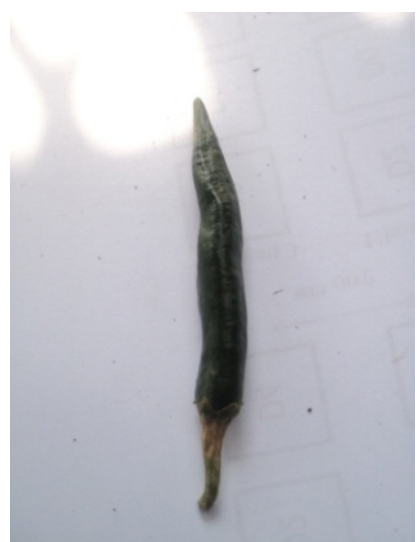

(a)

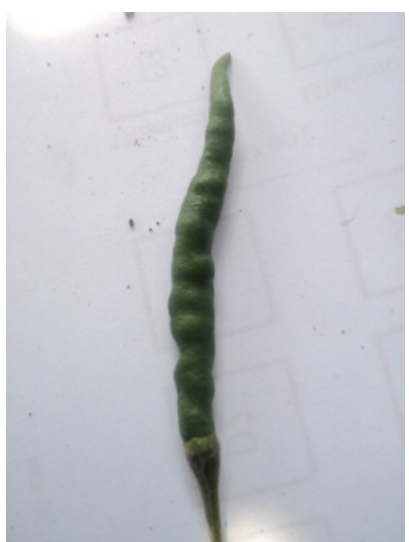

(b)

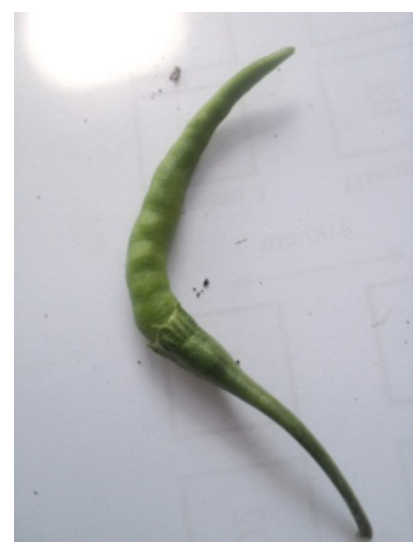

(c)

Gambar 2. Warna buah muda cabai yang diuji: (a) hijau tua (6 genotipe) (b) hijau (5 genotipe) (c) hijau muda (9 genotipe)

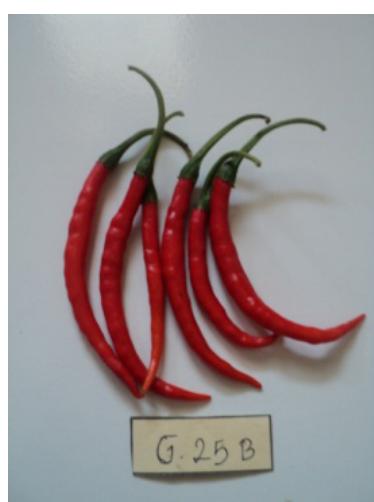

(a)

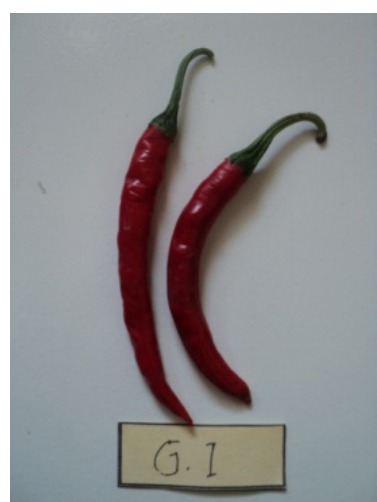

(b)

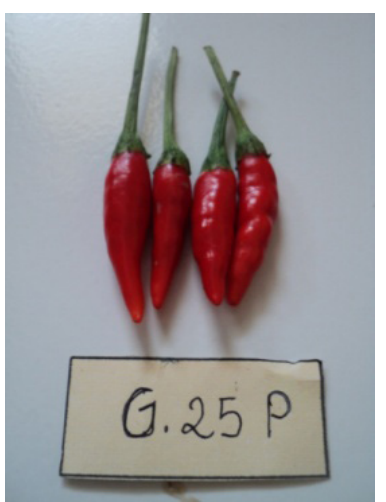

(c)

Gambar 3. Warna buah masak cabai yang diuji: (a) merah orange (6 genotipe) (b) merah (9 genotipe) (c) merah mengkilap (5 genotipe) 
gr . Rata-rata tertinggi yaitu pada genotipe ANIES sedangkan yang terendah pada genotipe IPBC4. Nilai duga heritabilitas pada peubah bobot perbuah dan bobot buah pertanaman menunjukkan kriteria yang luas sehingga seleksi pada peubah ini dapat dilakukan. Syukur et al. (2010) yang menyatakan bahwa nilai duga heritabilitas yang diamati memiliki kriteria yang tinggi pada peubah bobot buah pertanaman. Didukung hasil penelitian Syukur et al. (2011) yang menyatakan bahwa nilai duga heritabilitas untuk peubah bobot perbuah dan bobot buah pertanaman adalah tinggi sehingga pada peubah tersebut dapat dilakukan seleksi pada tahap awal.

\section{Peubah Kualitatif}

\section{Bunga}

Posisi tangkai bunga cabai pada penelitian ini yaitu tegak, horizontal dan menggantung. Hasil penelitian Natasya (2013) menyatakan posisi tangkai bunga yang dijumpai pada 25 genotipe cabai yang diamati yaitu tegak, semi tegak dan menggantung.

Warna corolla cabai pada penelitian ini yaitu putih, putih kekuningan, putih kehijauan dan putih garis ungu sesuai dengan IPGRI (1995). Warna corolla cabai yaitu putih dan putih kehijauan. Warna dasar bunga pada penelitian ini yaitu hijau muda, hijau tua dan hijau. Menurut Natasya (2013) warna dasar bunga yang diamati ada 5 macam yaitu kuning hijau muda, hijau muda, hijau, hijau tua dan ungu. Bentuk corolla pada penelitian ini yaitu memutar dan bintang sesuai dengan IPGRI (1995). Hasil penelitian Ariani (2009) bentuk corolla dari seluruh genotipe yang diamati yaitu rotate.

Warna anther pada penelitian ini yaitu biru, biru tua, hijau tua, hijau dan ungu. Menurut Susiana (2006) hampir semua genotipe yang digunakan berwarna ungu keputihan dan ungu Sedangkan menurut Ariani (2009) warna kehijauan mendominasi warna anther yang diamati.

Warna tangkai putik cabai pada penelitian ini yaitu putih, putih kekuningan dan ungu. Pada penelitian ini warna putih kekuningan lebih mendominasi yaitu terdapat pada 10 genotipe dari 20 genotipe cabai yang di tanam. Menurut IPGRI (1995) warna tangkai putik pada cabai yaitu putih, kuning, hijau, biru, orange dan ungu, sedangkan pada penelitian ini hanya ada 3 warna tangkai putik yaitu putih, putih kekuningan dan ungu sehingga masih banyak warna tangkai putik yang belum dijumpai pada penelitian ini.

\section{Buah}

Posisi buah pada penelitian ini yaitu tegak, horizontal dan menggantung. Menurut Ariani (2009) dari 21 genotipe cabai yang diamati posisi buah sebagian besar genotipe adalah kebawah, kecuali pada genotipe IPB C-10 yang orientasi buahnya menghadap keatas dan IPB C-15 dengan posisi buah horizontal.

Warna buah muda pada penelitian ini yaitu hijau tua, hijau muda dan hijau. Hasil penelitian Widyawati et al. (2014) menyatakan sebagian besar warna buah muda pada populasi F2 Prada adalah hijau tua $81 \%, 8 \%$ hijau dan $7.5 \%$ hijau muda. Sedangkan hasil penelitian Ariani (2009) warna buah muda seluruh genotipe adalah hijau dengan intensitas hijau yang berbedabeda.

Warna buah masak pada penelitian ini yaitu merah mengkilap, merah orange dan merah. Hasil penelitian Salamah (2013) warna buah masak pada 25 genotipe cabai yaitu orange kemerahan, merah muda, merah, merah tua, dan merah tua ujung ungu. 


\section{KESIMPULAN}

1. Terdapat keragaman genetik pada peubah kualitatif 20 genotipe cabai yang diamati. Posisi tangkai bunga : tegak, horizontal, dan menggantung. Warna corolla : putih, putih kehijauan, putih kekuningan, dan putih garis ungu. Warna tempat corolla 3 : hijau muda, hijau dan hijau tua. Bentuk corolla : lonceng dan memutar. Warna anther : biru, biru tua, hijau tua dan ungu. Warna tangkai putik : putih, putih kekuningan dan ungu. Warna buah muda : hijau muda, hijau dan hijau tua. Posisi buah : tegak, horizontal dan menggantung. Warna buah masak: merah, merah orange dan merah mengkilap.

2. Seleksi pada cabai dapat dilakukan berdasarkan karakter yang memiliki keragaman genetik yang luas dan heritabilitas yang tinggi yaitu peubah tinggi tanaman, waktu berbunga, umur panen, panjang buah, diameter buah, bobot perbuah dan bobot buah pertanaman.

\section{DAFTAR PUSTAKA}

Ajjapplavara, P.S. and R.F. Channagoudra. 2009. A Studies on variability, heritability and genetic advance in chili (Capsicum annuum L.). The Asian J. of Horticulture 4(1): 99-101.

Ariani, D.A. 2009. Pendugaan parameter genetik dan evaluasi daya hasil enam genotipe cabai half diallel pada intensitas cahaya rendah. Skripsi. Fakultas Pertanian. Institut Pertanian Bogor. Bogor. (tidak dipublikasikan).

BPS. 2015. Produksi cabai besar. http:// bps.go.id. Jadwal rilis : 2015-0803. Diakses pada tanggal 11 Januari 2016.
Dermawan, E. 2006. Kajian daya hasil 3 varietas cabai besar (Capsicum annuum L.) akibat pemberian jenis pupuk. Skripsi. Fakultas Pertanian. Universitas Jember. Jember. (tidak dipublikasikan).

Ganefianti, D.W., S. Sujiprihati, S.H. Hidayat dan M. Syukur. 2014. Keragaman genetik, heritabilitas dan korelasi antar karakter tanaman cabai yang diinfeksi begomovirus penyebab penyakit daun keriting kuning. Akta Agrosia 17(1) : 1-11.

Ganefianti, D.W., Yulian, dan A.N. Suprapti. 2006. Korelasi dan sidik lintas antara pertumbuhan, komponen hasil dan hasil dengan gugur buah pada tanaman cabai. Akta Agrosia 9(1):1- 6 .

Hilmayanti, I., W. Dewi, Murdaningsih, M. Rahardja, N. Rostini, dan R. Setiamihardja. 2006. Pewarisan karakter umur berbunga dan ukuran buah cabai merah (Capsicum annuum L.). Zuriat 17(1): 86-93.

IPGRI. 1995. Descriptor for Capsicum International Plant Genetic Resources Institute Rome. 47p.

Kirana, R dan E. Sofiari. 2007. Heterosis dan heterobeltiosis pada persilangan 5 hibrida cabai dengan metode dialel. J. Hort 17(2) : 111-117.

Lestari, A. D., W. Dewi, W. A. Qosim, M. Rahardja, N. Rostini, dan R. Setiamihardja. 2006. Variabilitas genetik dan heritabilitas karakter komponen hasil dan hasil lima belas genotip cabai merah. Zuriat 17(1): 94-102. 
Maflahah, I. 2010. Studi kelayakan industri cabe bubuk di Kabupaten Cianjur. Embryo 7: 90-96.

Marame, F., L. Desalegne, H. Singh, C. Fininsa, and R. Sigvald. 2008. Genetic components and heritability of yield and yield related traits in hot pepper. Res. J. Agric. \& Biol. Sci 4(6): 803-809.

Natasya, O. P. 2013. Identifikasi karakter kualitatif dan kuantitatif 25 genotipe cabai. Skripsi. Fakultas Pertanian. Universitas Bengkulu. Bengkulu. (tidak dipublikasikan).

Qosim, W.A., R. Meddy, S.H. Jajang, dan N. Ihsanudin. 2013. Penampilan fenotipik, variabilitas, dan heritabilitas 32 genotipe cabai merah berdaya hasil tinggi. J. Agron. Indonesia 41 (2) : 140 - 146 (2013).

Ramadhani, R., Damanhuri, dan L. P. Sri. 2013. Penampilan sepuluh genotipe cabai merah (Capsicum annuum L.). J. Produksi Tanaman 1(2): 33-41.

Salamah, U. 2013. Keragaman genetik dan heritabilitas sifat penting 25 genotipe tanaman cabai. Skripsi. Fakultas Pertanian. Universitas Bengkulu. Bengkulu (tidak dipublikasikan).

Saputra, M., Idwar, dan Deviona. 2013. Evaluasi keragaman 7 genotipe cabai (Capsicum annuum L.) di lahan gambut. Skripsi. Fakultas Pertanian. UNRI. Riau (tidak dipublikasikan).

Semangun, H. 2008. Penyakit-Penyakit Tanaman Hortikultura di Indonesia. Penerbit Gadjah Mada University Press. Yogyakarta.
Sharma, V.K., C.S. Semwal, and S.P. Uniyal. 2010. Genetic variability and character association analysis in bell pepper (Capsicum annuum L.). J. Hortic and For 2(3): 058-065.

Smitha, R. P. and N. Basvaraja. 2007. Variability and selection strategy for yield improvement in chili. Karnataka J. Agric. Sci 20(1):109-111.

Sreelathakumary, I., and L. Rajamony. 2004. Variability, heritability and genetic advance in chili (Capsicum annuum L.). J.Tro. Agri 42(1-2): 35-37.

Sujiprihati, S., G.B. Sale, and E.S. Ali. 2008. Heritability, performance and correlation studies on single cross hybrids of tropical maize. Asian J. Plant Sci 2(1): 51-57.

Susanto, G.W.A. dan M.M. Adie. 2005. Pendugaan heritabilitas hasil dan componen hasil galur-galur kedelai di tiga lingkungan. Prosiding Simposium PERIPI 5-7 Agustus 2004. hal: $119-125$.

Susiana, E. 2006. Pendugaan nilai heritabilitas, variabilitas dan evaluasi kemajuan genetik beberapa karakter agronomi genotipe cabai (Capsicum annuum L.) F4. Skripsi. Fakultas Pertanian. Institut Pertanian Bogor. Bogor. (tidak dipublikasikan).

Syukur, M., S. Sujiprihati, R. Yunianti, dan K. Nida. 2010. Pendugaan komponen ragam, heritabilitas dan korelasi untuk menentukan kriteria seleksi cabai (Capsicum annuum L.) populasi F5. J. Agrivigor 10(2): 148-156. 
Syukur, M.,S. Sriani, R. Yunianti, dan Darmawan, A. K. 2011. Pendugaan ragam genetik dan heritabilitas karakter komponen hasil beberapa genotipe cabai. J. Agrivigor 10(2): 148-156.

Syukur, M., R. Yunianti, dan R. Darmawan. 2012. Sukses Panen Cabai Tiap Hari. Penebar Swadaya. Jakarta.

Widyawati, Z., Y. Izmi, dan Respatijarti. 2014. Heritabilitas dan kemajuan genetik harapan populasi f2 pada tanaman cabai besar (Capsicum annuum L.) J. Produksi Tanaman 2(3): 247-252. 